\title{
Feed efficiency indexes and their relationships with carcass, non-carcass and meat quality traits in Nellore steers
}

\author{
M.L. Nascimento ${ }^{a}$, A.R.D.L. Souza ${ }^{\text {a }}$, A.S. Chaves ${ }^{\text {a,* }}$, A.S.M. Cesar ${ }^{\text {a }}$, R.R. Tullio ${ }^{\text {b }}$, S.R. Medeiros ${ }^{\text {c }}$, G.B. Mourão ${ }^{\text {a }}$, \\ A.N. Rosa ${ }^{\text {c }}$, G.L.D. Feijó ${ }^{c}$, M.M. Alencar ${ }^{\text {b }}$, D.P.D. Lanna ${ }^{\mathrm{a}}$ \\ a Department of Animal Science, University of São Paulo/ESALQ Piracicaba, São Paulo 13418-900, Brazil \\ b Embrapa Southeast Livestock, São Carlos, SP 13560-970, Brazil \\ c Embrapa Beef Cattle, Campo Grande, MS 79106-550, Brazil
}

\section{A R T I C L E I N F O}

\section{Article history:}

Received 6 March 2015

Received in revised form 18 December 2015

Accepted 25 January 2016

Available online 26 January 2016

Keywords:

Beef cattle

Bos indicus

Feed efficiency

Internal fat

Tenderness

Visceral organs

\begin{abstract}
A B S T R A C T
Five hundred and seventy-five Nellore steers were evaluated for residual feed intake and residual feed intake and gain and their relationships between carcass, non-carcass and meat quality traits. RFI was measured by the difference between observed and predicted dry matter intake and RIG was obtained by the sum of $-1 *$ RFI and residual gain. Efficient and inefficient animals were classified adopting \pm 0.5 standard deviations from RFI and RIG mean. A mixed model was used including RFI or RIG and contemporary group as fixed effects, initial age as covariate and sire and experimental period as random effects, testing the significance of the regression slope for each evaluated trait. RIG was positively related to longissimus muscle area. Efficient-RFI animals had lower liver and internal fat proportions compared to inefficient-RFI animals. Efficient-RFI and efficient-RIG animals had $11.8 \%$ and $11.2 \%$ lower extracted intramuscular fat, compared to inefficient-RFI and inefficient-RIG animals, respectively. Efficient-RFI animals had tougher meat compared to inefficient-RFI animals.
\end{abstract}

(c) 2016 Elsevier Ltd. All rights reserved.

\section{Introduction}

Brazil has the world's largest commercial cattle herd with a population of 211 million head, according to the Brazilian Institute of Geography and Statistics (IBGE, 2014). Approximately 80\% of this herd is comprised by Bos indicus, $90 \%$ of which is composed of the Nellore breed (Brazilian Association of Meat Exporters - ABIEC, 2014). In 2013, circa 26.7 million animals were slaughtered, resulting in the production of 10.2 million tons of equivalent carcass (IBGE, 2014).

Feed efficiency is an important aspect for the reduction of feed and feeding costs and, thus, to increase profitability for the activity since feed costs may account for $55-75 \%$ of the total costs of beef production, excluding costs of animal acquisition (Arthur, Archer, Herd, \& Melville, 2001).

In Brazil, feed efficiency is traditionally measured by feed conversion ratio ( $\mathrm{kg} \mathrm{DMI} \mathrm{(dry} \mathrm{matter} \mathrm{intake)/kg} \mathrm{gain)} \mathrm{or} \mathrm{its} \mathrm{inverse,} \mathrm{gain:feed} \mathrm{ratio.}$ However, both are associated with growth rate (Herd \& Bishop, 2000), thus genetic selection for those indexes may result in an increased adult size as well as higher nutrient demand from the selected animals.

\footnotetext{
* Corresponding author.

E-mail address: amaliaschaves@yahoo.com.br (A.S. Chaves).
}

Residual feed intake (RFI), calculated as the difference between observed and predicted DMI (Koch, Swigwr, Chambers, \& Gregory, 1963), has been studied as an index of feed efficiency. Differently from the gain:feed ratio, selection based on RFI does not increase mature size of the herd because it is adjusted to growth rate, allowing the identification of animals with lower feed intake and methane production at the same body weight and gain (Jones, Philips, Naylor, \& Mercer, 2011; Khiaosa-Ard \& Zebeli, 2014). In addition, RFI-efficient animals seem to produce leaner carcasses with lower subcutaneous fat thickness and extracted intramuscular fat in longissimus muscle, important features to ensure meat quality (Gomes et al., 2012; Herd \& Pitchford, 2011; Zorzi et al., 2013).

Residual intake and gain (RIG) recently proposed by Berry and Crowley (2012) is a new feed efficiency index that associates RFI and residual gain (RG), obtained by the difference between observed and predicted average daily gain (Koch et al., 1963). The most efficient animals based on RIG have both lower feed intake and greater BWG (body weight gain) at the same time, thus, it is more closely related to profitability than RFI.

Before including feed efficiency indexes in breeding programs, it is crucial to understand their phenotypic relationships with carcass and meat quality traits, avoiding the fact that future benefits achieved by reducing production costs are unfavorable changes in the final product. 
This study investigated the phenotypic relationships between RFI, RIG and performance traits with carcass, non-carcass and meat quality traits of Nellore steers finished in feedlot.

\section{Materials and methods}

\subsection{Animals and diets}

Animals were handled and managed according to the Institutional Animal Care and Use Committee Guidelines (Brazilian Agricultural Research Corporation - EMBRAPA, Brazil). Data from three years, where the animals had similar nutritional history (grazing systems), were used, totalling 575 steers from 34 sires, chosen to represent the main genealogies of the Nellore breed (Fig. 1).

The half-sib families were produced by artificial insemination in commercial and pure bred Nellore dams. Animals were born in three different ranches in spring of 2007, 2008 and 2009, where they stayed for about $21 \mathrm{mo}$. Feed efficiency tests were carried out for $3 \mathrm{yr}$, from November 2009 to December 2011, at two different feedlots of Brazilian Agricultural Research Corporation (Embrapa - Embrapa Southeast Livestock (São Carlos, SP, Brazil - Feedlot 1) and Embrapa Beef Cattle (Campo Grande, MS, Brazil - Feedlot 2) for at least $70 \mathrm{~d}$.

The adaptation period was at least $28 \mathrm{~d}$. After the adaptation period, according to the body weight and sire, the animals were allocated in individual or collective pens. The collective pens were equipped with Calan gate feeding system (American Calan Inc., Northwood, New Hampshire, USA), allowing to obtain individual intake of nine animals per pen (Table 1 ).

The animal were fed twice daily in excess to result in $5 \%$ of food refusals, with diet containing around $40 \%$ silage and $60 \%$ concentrate on a DM basis (Table 2).

Samples of diet and individual food refusals were collected weekly, dried in forced ventilation oven $\left(55^{\circ} \mathrm{C} \pm 5{ }^{\circ} \mathrm{C} / 72 \mathrm{~h}\right)$ and ground in a Willey-type mill $(1 \mathrm{~mm})$ to obtain composite samples at the end of the trial period. The samples were analyzed for the following fractions and methodologies: dry matter (DM) at $105^{\circ} \mathrm{C}$, ash and crude protein (CP) (AOAC, 2006), neutral detergent fiber (NDF), acid detergent fiber (ADF) and lignin (Van Soest, Robertson, \& Lewis, 1991); N-NDF and N-ADF (Licitra, Hernandez, \& Van Soest, 1996) and ether extract (AOCS Am 5-04, 2006).

\subsection{Trial period and feed efficiency evaluation period}

After the adaptation period the initial weight was determined following $16 \mathrm{~h}$ of feed and water fasting, designating the start of the trial. The total trial period corresponded to the difference between the first weighing and the harvesting, when animal reached $5 \mathrm{~mm}$ subcutaneous fat thickness (Fig. 1).

In each feedlot within a year, DMI and BWG were individually measured for at least the first $70 \mathrm{~d}$ of the trial, corresponding to the feed efficiency evaluation period. Animals that reached $5 \mathrm{~mm}$ before remained on the test until $70 \mathrm{~d}$. According to the Australian protocol
Table 1

Mean and standard error mean (SEM) and range of initial body weight and age of Nellore steers tested for residual feed intake (RFI) and residual feed intake and gain (RIG) in function of feedlot location and the pen type.

\begin{tabular}{|c|c|c|c|c|c|c|c|}
\hline $\begin{array}{l}\text { Feedlot } \\
\text { location }^{\text {a }}\end{array}$ & Year & Pen type & $\mathrm{N}$ & $\begin{array}{l}\text { Initial age } \\
\text { (d) }\end{array}$ & SEM & $\begin{array}{l}\text { Initial BW } \\
(\mathrm{kg})\end{array}$ & SEM \\
\hline \multirow[t]{5}{*}{ São Carlos } & \multirow[t]{2}{*}{1} & Collective $^{\mathrm{b}}$ & 85 & 712 & 2.00 & 390.8 & 3.93 \\
\hline & & Individual & 41 & 702 & 2.90 & 386.8 & 6.65 \\
\hline & \multirow[t]{2}{*}{2} & Collective $^{\mathrm{b}}$ & 88 & 604 & 2.45 & 330.7 & 4.14 \\
\hline & & Individual & 66 & 606 & 3.06 & 326.2 & 4.33 \\
\hline & 3 & Individual & 79 & 610 & 3.22 & 298.3 & 3.32 \\
\hline \multirow[t]{3}{*}{ Campo Grande } & 1 & Individual & 66 & 665 & 2.48 & 367.5 & 3.45 \\
\hline & 2 & Individual & 82 & 671 & 2.93 & 386.3 & 4.18 \\
\hline & 3 & Individual & 71 & 630 & 4.13 & 401.9 & 5.80 \\
\hline
\end{tabular}

a Embrapa Southeast Livestock (São Carlos, SP, Brazil - Feedlot 1) and Embrapa Beef Cattle (Campo Grande, MS, Brazil - Feedlot 2).

b Collective pens equipped with Calan gate feeding system (American Calan Inc., Northwood, New Hampshire, USA), allowing to obtain individual intake of nine animals per pen.

(Arthur et al., 2001) at least $70 \mathrm{~d}$ of intake and weight gain are required to determine RFI.

Body weight (BW) was obtained every two weeks before feeding to minimize differences in animal gut fill but with no food and water restriction. Initial body weight (IBW, $\mathrm{kg}$ ) and final body weight (FBW, $\mathrm{kg}$ ) of the feed efficiency evaluation period, as well as the weighing at preslaughter were also measured following $16 \mathrm{~h}$ of feed and water fasting. The mid-test metabolic body weight (MMBW) was calculated as the mean between IBW and FBW.

Average daily gain (ADG, $\mathrm{kg} / \mathrm{d}$ ) during the feed efficiency evaluation period and the total experimental period were estimated by regression between BW and days on feed using proc. REG (Sas Institute, 2012), where the slope represents growth rate.

Individual DMI ( $\mathrm{kg} / \mathrm{d})$ was obtained by the difference between offer and refusal of DM. The DM content of the diet and food refusals were determined weekly. At the end of the trial period, DM was corrected to definitive $\mathrm{DM}\left(105^{\circ} \mathrm{C}\right)$ using individual composite samples of refusals and diet.

\subsection{Feed efficiency traits and calculations}

Residual feed intake (RFI, $\mathrm{kg} / \mathrm{d}$ ) and residual gain ( $\mathrm{RG}, \mathrm{kg} / \mathrm{d}$ ) were computed by regression of DMI, BW ${ }^{0.75}$ and ADG (Koch et al., 1963) using MIXED procedure (Sas Institute, 2012), resulting in these equations:

$\mathrm{DMI}=-2.711+0.106 \mathrm{MMBW}+1.240 \mathrm{ADG}+\varepsilon 1$

$\mathrm{ADG}=0.523-0.004 \mathrm{MMBW}+0.131 \mathrm{DMI}+\varepsilon 2$

where $\varepsilon 1$ represents residual feed intake (RFI) and $\varepsilon 2$ residual gain (RG). For both indexes the model included the random effect of the contemporary group, defined by year, feedlot site, place of birth, RFI
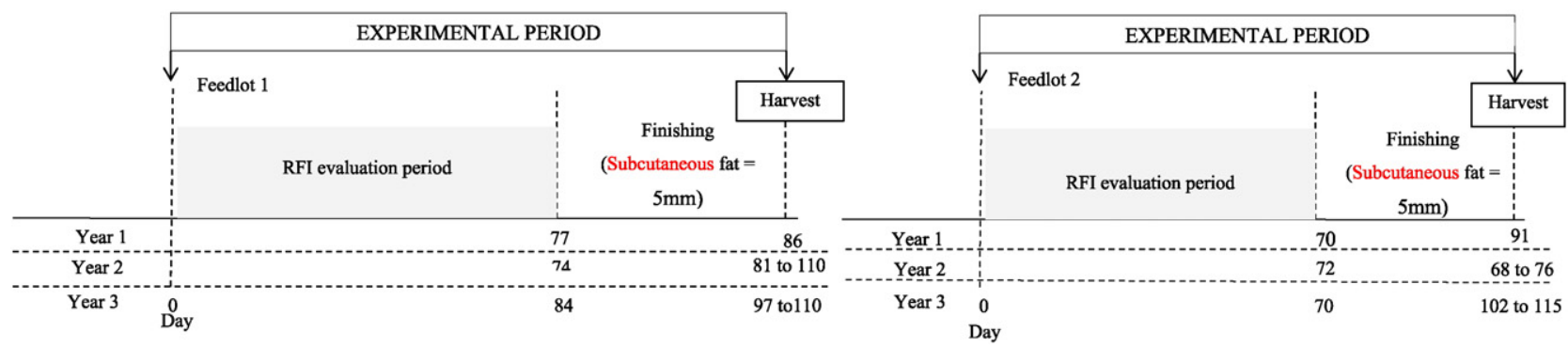

Fig. 1. Experimental design in both feedlots for 3 different years of evaluation. 
Table 2

Ingredients and composition of experimental diets.

\begin{tabular}{|c|c|c|c|c|c|}
\hline \multirow{2}{*}{$\begin{array}{l}\text { Feedlot site } \\
\text { Year }\end{array}$} & \multicolumn{2}{|c|}{ Sao Carlos } & \multicolumn{3}{|c|}{ Campo Grande } \\
\hline & 1 and 2 & 3 & 1 & 2 & 3 \\
\hline Corn silage & 39.88 & 44.03 & - & - & - \\
\hline Sorghum silage & - & - & 40.00 & 40.00 & 39.00 \\
\hline Ground corn grain & 31.62 & 29.45 & 32.00 & 31.52 & 32.00 \\
\hline Soybean hull & 10.08 & 9.25 & 10.00 & 10.00 & 10.20 \\
\hline Soybean & - & - & 11.25 & - & - \\
\hline Cotton seed & 8.21 & 7.76 & - & 8.00 & 8.20 \\
\hline Soybean meal 45\% & 8.78 & 8.17 & 4.89 & 9.00 & 9.15 \\
\hline Limestone & 0.48 & 0.45 & 1.16 & 0.50 & 0.50 \\
\hline Urea & 0.24 & 0.23 & - & 0.25 & 0.25 \\
\hline Mineral premix ${ }^{a}$ & 0.68 & 0.63 & 0.67 & 0.67 & 0.67 \\
\hline Monensin ${ }^{\mathrm{b}}$ & 0.03 & 0.03 & 0.03 & 0.03 & 0.03 \\
\hline \multicolumn{6}{|l|}{ Composition } \\
\hline DM & 50.90 & 59.19 & 50.10 & 51.0 & 50.74 \\
\hline Ash & 4.44 & 4.19 & 5.29 & 5.76 & 4.63 \\
\hline $\mathrm{CP}$ & 13.54 & 15.73 & 15.35 & 15.36 & 15.05 \\
\hline NDIP $^{\mathrm{c}}$ & 13.74 & 16.65 & 15.03 & 14.60 & 13.87 \\
\hline $\mathrm{ADIP}^{\mathrm{d}}$ & 4.21 & 7.95 & 5.74 & 4.41 & 6.59 \\
\hline $\mathrm{EE}$ & 3.84 & 4.22 & 5.41 & 4.17 & 4.42 \\
\hline NDF & 34.08 & 43.39 & 38.35 & 39.47 & 41.25 \\
\hline $\mathrm{NDFp}^{\mathrm{e}}$ & 31.08 & 40.78 & 33.32 & 34.87 & 39.16 \\
\hline $\mathrm{ADF}$ & 20.32 & 31.14 & 26.50 & 25.40 & 27.33 \\
\hline Lignin & 2.59 & 3.76 & 3.22 & 3.12 & 3.42 \\
\hline NFC & 46.88 & 35.09 & 38.77 & 39.06 & 35.99 \\
\hline $\mathrm{TDN}^{\mathrm{f}}$ & $73.61^{\mathrm{h}}$ & $71.03^{\mathrm{h}}$ & 73.09 & 72.44 & 73.14 \\
\hline $\mathrm{ME}^{\mathrm{g}}$ & 2.80 & 2.63 & 2.65 & 2.60 & 2.64 \\
\hline
\end{tabular}

a Composition by kilogram: Phosphorus ( $85 \mathrm{~g})$, Calcium (130 g), Magnesium ( $5 \mathrm{~g}$ ), Sulfur (25 g), Sodium (156 g), Chlorine (240 g), Zinc (5000 mg), Copper (1500 mg), Iron (1700 mg), Manganese (1250 mg), Cobalt (120 mg), Iodine (120 mg) and Selenium (15 mg).

b $28 \mathrm{mg} / \mathrm{kg}$ of DM.

c \% DM basis.

d \% CP basis.

e FDNp - FDN corrected to protein.

f Estimated according to Weiss, Conrad, and Pierre (1992).

g $\mathrm{Mcal} / \mathrm{kg}$ of DM.

h Processing factor (0.94) used according to NRC (2001).

evaluation period and pen type, totaling 21 contemporary groups, ranging from 10 to 79 animals per group.

The residual intake and gain (RIG) was computed by adding RFI multiplied by minus 1 and RG of each animal, both previously standardized to variance 1 using the STANDARD procedure of SAS (Sas Institute, 2012).

$\mathrm{RIG}=1 * \mathrm{RFI}+\mathrm{RG}$

Gain:feed ratio (G:F) was computed by the ratio between ADG $(\mathrm{kg} / \mathrm{d})$ and DMI (kg/d).

\subsection{Carcass and non-carcass traits}

Subcutaneous fat thickness ( $\mathrm{mm}$ ) and longissimus muscle area $\left(\mathrm{cm}^{2}\right)$ at the 12-13th ribs were obtained at the initial, middle and final feed efficiency evaluation periods as well as the day prior to the harvesting. After the 70 day period the animals were scanned biweekly until they reached at least $5 \mathrm{~mm}$ of subcutaneous fat thickness. Animals were scanned by a certified technician using an Aquila Pie Medical ultrasound (Pie Medical, Inc. Maastricht, The Netherlands) with a $17-\mathrm{cm}$ 3.5 $\mathrm{MHz}$ transducer. Images were collected and processed using software ODT Eview ${ }^{\circledR}$ (Pie Medical, Inc. Maastricht, The Netherlands).

When subcutaneous fat thickness measured by ultrasound reached at least $5 \mathrm{~mm}$, the animals were harvested and sent to a commercial packing plant after fasting from water and solids for $16 \mathrm{~h}$ to obtain shrunk body weight (SBW). Animals were stunned by brain concussion, then exsanguinated through the jugular vein, carcasses were hung by the Achilles tendon with no electrical stimulation. Head, feet, leather and visceral organs were removed and heart, kidney, liver and perirenal, pelvic and inguinal fats were weighed.

Carcasses were weighed and chilled for $24 \mathrm{~h}$ at $5{ }^{\circ} \mathrm{C}$. Hot dressing percentage (\%) was calculated as the ratio between hot carcass weight (HCW) and SBW the day before harvesting. At $24 \mathrm{~h}$ post mortem, length was measured as the distance between anterior border of the pubic bone and medial cranial border of the first rib on the left half-carcass. Likewise, carcass depth was taken on the 5th rib from top to bottom measuring the distance from sternum to middle of the spine where the marrow bone passes.

Half-carcasses were divided into forequarter (with five ribs), hindquarter and spare ribs (Barros \& Vianni, 1979). On the hindquarter of the left half-carcass, a cross-section was made between the 12-13th ribs to measure the subcutaneous fat thickness with a caliper rule and longissimus muscle area (LMA) with a grid.

\subsection{Meat quality traits}

Meat samples of animals of feedlot 2 in year 1 were not included due to sampling problems, therefore samples of 512 animals were used for the analysis of meat quality traits.

At $24 \mathrm{~h}$ post mortem, three steaks ( $2.5 \mathrm{~cm}$ thick) were removed from the longissimus corresponding to the 10-11-12th ribs of the left halfcarcass. One steak was used to measure meat quality traits at $24 \mathrm{~h}$ post mortem, while the other two were vacuum-packaged and cooled $\left(2{ }^{\circ} \mathrm{C}\right)$ until 7 and $14 \mathrm{~d}$ post mortem, respectively, and then frozen $\left(-30^{\circ} \mathrm{C}\right)$ for later analysis.

Longissimus samples were also collected to determine myofibril fragmentation index, humidity, extracted intramuscular fat and water holding capacity. Prior to the meat quality analysis, aged frozen steaks were thawed $\left(5^{\circ} \mathrm{C}\right)$ until an internal temperature of $4{ }^{\circ} \mathrm{C}$ was reached.

Thirty minutes before meat color measurements, a cross cut was made in the steak to expose the surface layer, which promoted myoglobin oxygenation. Color of meat and subcutaneous fat was obtained in a Mini Scan XE Plus 45/0 (HunterLab), with a port diameter $31.8 \mathrm{~mm}$. Standardization of the apparatus was made using a standard black and white pattern coordinates for standard light D65 (daylight $6500 \mathrm{~K}$ ) and $10^{\circ}$ standard observer. Color parameters were determined according to the CIELAB scale (CIE, 1978), illuminant D65 and $10^{\circ}$ standard observer (Honikel, 1998). Three readings of $\mathrm{L}^{*}, \mathrm{a}^{*}$ and $\mathrm{b}^{*}$ values were obtained at three different portions of the samples (Ramos \& Gomide, 2007).

The $\mathrm{pH}$ was measured in the muscular portion and in three different portions of the samples using a digital $\mathrm{pH}$ meter (Text, $£ 230$ ). Water holding capacity (\%) was determined using filter paper press methodology with about $2 \mathrm{~g}$ of the longissimus sample. The difference between sample weight before and after pressure ( $10 \mathrm{~kg}$ for $5 \mathrm{~min}$ ) as well as sample humidity was used in the calculation (Grau \& Hamm, 1953).

Steaks were baked in an electric oven (Tedesco, TC06/ELT model) at a temperature of approximately $170{ }^{\circ} \mathrm{C}$. The internal temperature was monitored with individual thermometers placed in the geometric center of the sample. When the internal temperature reached $70{ }^{\circ} \mathrm{C}$, the samples were removed from the oven and left to cool at room temperature.

Samples were wrapped in plastic film and, after cooling overnight, eight cores ( $1.27 \mathrm{~cm}$ in diameter) were removed parallel to the longitudinal orientation of the muscle fibers. Each core was sheared once with a texture analyzer "TA.XT2i" coupled to a Warner-Bratzler blade with $1.016 \mathrm{~mm}$ thickness, according to Wheeler, Koomarie, and Shalckelford (2005).

Cooking losses were obtained from the weight difference of the steaks before and after cooking. Myofibrillar fragmentation index was determined according to Hopkins, Littlefeld, and Thompson (2000). The extracted intramuscular fat was quantified in lyophilized longissimus samples according to AOCS procedure Am 5-04 (2005), using an Ankom extractor (Model XT20). 
Table 3

Mean, standard deviation (SD) and range of performance traits of Nellore steers tested for residual feed intake (RFI) and residual feed intake and gain (RIG) during the feed efficiency evaluation period.

\begin{tabular}{lcccc}
\hline Traits & Mean & SD & Minimum & Maximum \\
\hline $\mathrm{N}=575$ & & & & \\
Initial age, d & 648 & 47.8 & 542 & 746 \\
Final age, d & 719 & 47.1 & 612 & 822 \\
Initial body weight, kg & 360 & 51.8 & 233 & 513 \\
Final body weight, kg & 453 & 45.5 & 332 & 598 \\
Average daily gain, kg/d & 1.28 & 0.339 & 0.311 & 2.17 \\
Dry matter intake, kg/d & 8.44 & 1.263 & 5.37 & 12.78 \\
Dry matter intake, \% BW & 2.08 & 0.235 & 1.53 & 2.91 \\
Residual feed intake, kg/d & 0.00 & 0.629 & -1.76 & +2.05 \\
Residual gain, kg/d & 0.00 & 0.203 & -0.686 & +0.649 \\
Residual intake and gain, kg/d & 0.00 & 1.672 & -5.11 & +4.88 \\
\hline
\end{tabular}

\subsection{Statistical analyses}

The variables were analyzed by multiple linear regression where the studied traits were considered response variables (Y) and RFI or RIG as independent variables $(\mathrm{X})$, using mixed models that allow estimation of fixed effects, such as contemporary group (CG) and random genetic effects, namely the sire effect. Analyses were performed using PROC MIXED of the SAS (Sas Institute, 2012) where the CG was defined according to the feedlot site, year, place of birth, feed efficiency evaluation period and pen type.

To illustrate the differences between efficient and inefficient animals in terms of RFI and RIG, the animals were classified adopting the classical criterion used in the literature (Koch et al., 1963), that is, \pm 0.5 standard deviations from RFI and RIG mean.

The model considered contemporary group and RFI or RIG as fixed effects, initial age as covariate, and sire as random effect according to the statistical model described below:

$y_{i j k t}=\mu+\beta_{i}+\gamma_{j}+\rho_{k}+\alpha_{t}+e_{i j t k}$

where $\mu$ is the fixed overall mean effect; $\beta_{i}$ is fixed RFI or RIG effect; $\gamma_{j}$ is fixed CG effect; $\rho_{k}$ is covariate effect of initial age, $\alpha_{t}$ is the random effect of sire and $e_{i j k} t$ is the random residual error associated with $y_{i j k t}$.

For traits evaluated after slaughter, as carcass traits and meat quality, was included in previous model experiment time as a random effect, since the slaughter time was determined when animals reached at least $5 \mathrm{~mm}$ of subcutaneous fat thickness.

$y_{i j k t u}=\mu+\beta_{i}+\gamma_{j}+\rho_{k}+\alpha_{t}+\sigma_{\mathrm{u}}+e_{i j k t u}$

where $\mu$ is the fixed overall mean effect, $\beta_{i}$ is fixed RFI or RIG effect, $\gamma_{j}$ is fixed CG effect, $\rho_{k}$ is covariate effect of initial age, $\alpha_{t}$ is the random effect of sire, ou is random effect of experiment time and $e_{i j k t u}$ is the random residual error associated with $y_{i j k t u}$.
The interpretation of the regression coefficient with RFI $\left(\beta_{1}\right)$ and RIG $\left(\beta_{2}\right)$ represents the expected variation on studied traits for one unit variation in RFI ( $\mathrm{kg} \mathrm{DM}$ /day) or RIG.

RFI and RIG means of the efficient and inefficient classes were then used in the regression equation for each trait, using the ESTIMATE function of PROC MIXED, in order to predict the value that the trait would assume if RFI or RIG had the value corresponding to the class mean, considering the mean initial age of the animals. Therefore, if the coefficient $\beta_{1}$ or $\beta_{2}$ is significant, the mean of efficient and inefficient animals also differ, since the difference between them is larger than 1 unit of RFI or RIG. Data were considered statistically significant when $\mathrm{P}<0.05$.

\section{Results and discussion}

\subsection{Carcass and non-carcass traits}

Descriptive statistics of 575 Nellore steers for performance traits are presented in Table 3. Similar values were obtained in other studies on feed efficiency in beef cattle (Nkrumah et al., 2007; Zorzi et al., 2013). The range of 3.8 units for RFI and 9.9 units for RIG indicates great phenotypic variability for these efficiency indexes, which was expected due to the selection of the sires to express the greatest possible variability in genetic background of Nellore breed.

Of the evaluated animals, $30.1 \%$ was considered efficient (RFI lower than $-0.315 \mathrm{~kg} \mathrm{DM} / \mathrm{d}, \mathrm{N}=173$ ) and $29.9 \%$ was considered inefficient (RFI greater than $+0.315 \mathrm{~kg} \mathrm{~kg} \mathrm{DM} / \mathrm{d}, \mathrm{N}=172$ ), while the others had RFI between -0.5 and $0.5 \mathrm{SD}$ of the mean $(\mathrm{N}=230)$. In terms of RIG, $30.6 \%$ had RIG lower than -0.5 SD of the mean and was considered inefficient $(\mathrm{N}=176)$ and $29.6 \%$ had RIG greater than $+0.5 \mathrm{SD}$ and was considered efficient $(\mathrm{N}=170)$, while the other animals had RIG between -0.5 and $0.5 \mathrm{SD}$ of the mean $(\mathrm{N}=229)$.

As expected, there was no significant relationship $(P>0.05)$ between RFI and initial and final body weights ( $P>0.05$, Table 4 ), since RFI is adjusted to metabolic body weight and ADG, corroborating with results reported in the literature (Koch et al., 1963; Santana et al., 2014; Zorzi et al., 2013). Residual feed intake was not related to ADG $(\mathrm{P}>0.05)$ however, RIG was positively correlated to FBW and ADG $(P<0.05)$. For each unit of RIG, ADG increased $70 \mathrm{~g} / \mathrm{d}$, that is, efficient animals had $25.7 \%$ greater ADG than RIG inefficient animals. This is expected since residual gain is included in RIG estimation, which allows the identification of individuals with greater ADG. Berry and Crowley (2012) and Retallick (2013) also observed greater ADG in RIG-efficient animals.

Reduction in DMI was observed for efficient animals selected by RFI or RIG $(\mathrm{P}<0.05)$. Decreasing $1 \mathrm{~kg} \mathrm{DM} / \mathrm{d}$ of RFI resulted in a decrease of $0.98 \mathrm{~kg} \mathrm{DM} / \mathrm{d}(\mathrm{P}<0.0001)$ and an increase of $1 \mathrm{~kg} \mathrm{DM} / \mathrm{d}$ on RIG resulted in a decrease of $0.22 \mathrm{~kg} \mathrm{DM} / \mathrm{d}(\mathrm{P}<0.0001)$, according to linear regression coefficients for RFI and RIG respectively (Table 3 ). These results are in agreement with the literature (Ahola, Skow, Hunt, \& Hill, 2011;

Table 4

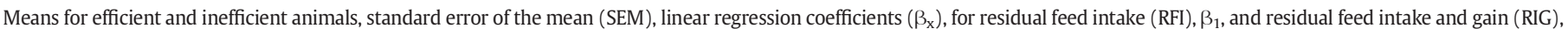
$\beta_{2}$, and probability level for performance traits of 575 Nellore steers. TDN according to Weiss et al. (1992).

\begin{tabular}{|c|c|c|c|c|c|c|c|c|c|c|}
\hline \multirow[t]{2}{*}{ Traits } & \multicolumn{5}{|l|}{ RFI } & \multicolumn{5}{|l|}{ RIG } \\
\hline & Efficient & Inefficient & SEM & $\beta_{1}$ & P-value & Efficient & Inefficient & SEM & $\beta_{2}$ & P-value \\
\hline \multicolumn{11}{|l|}{$\mathrm{N}=575$} \\
\hline Residual feed intake, $\mathrm{kg} / \mathrm{d}$ & .. & .. & .. & .. &.. & -0.606 & 0.629 & 0.02 & -0.32 & $<0.0001$ \\
\hline Residual intake and gain, $\mathrm{kg} / \mathrm{d}$ & 1.63 & -1.57 & 0.06 & -2.23 & $<0.0001$ &.. & .. & .. &.. & .. \\
\hline Initial body weight, $\mathrm{kg}^{3}$ & 367 & 366 & 2.34 & -0.72 & 0.74 & 363 & 370 & 3.01 & -1.87 & 0.03 \\
\hline Final body weight, kg & 456 & 454 & 3.11 & -0.94 & 0.72 & 462 & 449 & 3.63 & 3.26 & 0.001 \\
\hline Average daily gain, $\mathrm{kg} / \mathrm{d}$ & 1.24 & 1.24 & 0.02 & -0.00 & 0.97 & 1.37 & 1.09 & 0.01 & 0.07 & $<0.0001$ \\
\hline Dry matter intake, $\mathrm{kg} / \mathrm{d}$ & 7.77 & 9.18 & 0.06 & 0.98 & $<0.0001$ & 8.04 & 8.89 & 0.07 & -0.22 & $<0.0001$ \\
\hline Dry matter intake, \% BW & 1.88 & 2.24 & 0.00 & 0.25 & $<0.0001$ & 1.95 & 2.17 & 0.01 & -0.06 & $<0.0001$ \\
\hline TDN intake, $\mathrm{kg} / \mathrm{d}$ & 5.52 & 6.61 & 0.05 & 0.76 & $<0.0001$ & 5.72 & 6.39 & 0.05 & -0.17 & $<0.0001$ \\
\hline
\end{tabular}


Table 5

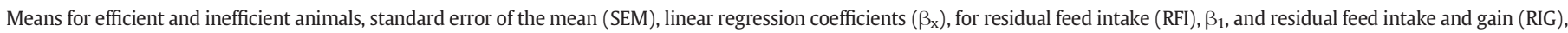
$\beta_{2}$, and probability level for carcass traits of 575 Nellore steers.

\begin{tabular}{|c|c|c|c|c|c|c|c|c|c|c|}
\hline \multirow[t]{2}{*}{ Traits } & \multicolumn{5}{|l|}{ RFI } & \multicolumn{5}{|l|}{ RIG } \\
\hline & Efficient & Inefficient & SEM & $\beta_{1}$ & P-value & Efficient & Inefficient & SEM & $\beta_{2}$ & P-value \\
\hline \multicolumn{11}{|l|}{$\mathrm{N}=575$} \\
\hline Shrunk body weight, kg & 454 & 450 & 5.5 & -3.36 & 0.14 & 462 & 448 & 5.42 & 3.37 & $<0.0001$ \\
\hline Hot carcass weight, kg & 254 & 251 & 3.0 & -2.29 & 0.09 & 258 & 250 & 2.94 & 1.92 & $<0.0001$ \\
\hline Hot dressing, \% & 55.8 & 55.7 & 0.12 & -0.08 & 0.37 & 55.8 & 55.8 & 0.11 & -0.00 & 0.96 \\
\hline Depth, $\mathrm{cm}^{\mathrm{b}}$ & 39.3 & 39.3 & 0.28 & -0.01 & 0.91 & 39.3 & 39.2 & 0.28 & 0.03 & 0.09 \\
\hline Length, $\mathrm{cm}^{\mathrm{c}}$ & 124 & 124 & 0.44 & -0.01 & 0.98 & 125 & 124 & 0.40 & 0.22 & 0.01 \\
\hline Hindquarter, $\%^{\mathrm{a}}$ & 48.1 & 48.1 & 0.10 & 0.01 & 0.95 & 48.2 & 48.1 & 0.08 & 0.03 & 0.38 \\
\hline Forequarter, $\%^{\mathrm{a}}$ & 39.8 & 39.8 & 0.16 & 0.01 & 0.95 & 39.8 & 39.8 & 0.16 & -0.01 & 0.86 \\
\hline Spare ribs, $\%^{\mathrm{a}}$ & 12.7 & 12.9 & 0.07 & 0.12 & 0.03 & 12.7 & 12.8 & 0.07 & -0.04 & 0.12 \\
\hline Longissimus muscle area, $\mathrm{cm}^{2}$ & 62.0 & 60.5 & 0.83 & -0.98 & 0.02 & 62.5 & 60.6 & 0.81 & 0.50 & 0.00 \\
\hline Subcutaneous fat thickness, $\mathrm{mm}$ & 6.10 & 6.15 & 0.31 & 0.03 & 0.81 & 6.15 & 6.08 & 0.31 & 0.03 & 0.44 \\
\hline
\end{tabular}

a $\mathrm{N}=356$.

b Depth of carcass: taken on the 5th rib from top to bottom measuring the distance from sternum to middle of the spine where the marrow bone passes.

c Length of carcass: measured as the distance between anterior border of the pubic bone and medial cranial border of the first rib on the left half-carcass.

Berry \& Crowley, 2012; Gomes et al., 2012; Lucila Sobrinho et al., 2011; Retallick, 2013; Santana et al., 2014; Santana, Rossi Junior, Almeida, \& Cucco, 2012; Welch et al., 2012; Zorzi et al., 2013). Lower DMI of efficient animals may be attributed to lower maintenance requirement, lower energy content of body gain or higher efficiency in using energy for gain. Maintenance requirements are associated with the processes of heat production for thermoregulation, heat increment, muscle activity, blood circulation, respiration and tissue renewal, and are directly affected by the size and weight of organs, particularly liver, heart and kidney, which have higher metabolic rates (Ferrell \& Jenkins, 1998).

RFI was independent of hot carcass weight (HCW) and hot dressing ( $P>0.05$; Table 5 ), which was expected since RFI is adjusted to BW and $\mathrm{HCW}$ is directly related to the BW. The same reasoning can be applied to results of length and depth of carcass, which were not related to RFI $(P>0.05)$ since body size and weight are closely related to each other. Other authors also found no association between RFI and carcass weights and dimensions in beef cattle (Baker et al., 2006; Bonilha et al., 2013; Cruz, Rodriguez-Sanchez, Oltjen, \& Sainz, 2010; Gomes et al., 2012; McDonagh et al., 2001; Nkrumah et al., 2004; Welch et al., 2012; Zorzi et al., 2013).

RIG was not related to hot dressing and carcass depth $(P>0.05)$, however, RIG-efficient animals had higher HCW and carcass length compared to inefficient ones $(\mathrm{P}<0.05)$. These results are in accordance with greater ADG and FBW presented by the efficient-RIG-animals (Table 4). Cancian et al. (2014), evaluating the relationship between RFI, HCW and hot dressing (\%) of Nellore steers, found no significant relationship between RFI and those carcass parameters. Spare rib proportion (\%) was lower in RFI-efficient animals $(P<0.05)$, but efficient and inefficient-RIG animals had no differences for spare rib proportion $(P>0.05)$. These results are in disagreement with those found by Zorzi et al. (2013) where RFI did not affect spare rib proportion of Nellore bulls, but the herein observed difference is quite small, equivalent to $0.5 \mathrm{~kg}$ of additional carcass in about $32 \mathrm{~kg}$ of spare ribs. Forequarter and hindquarter proportions were not related to RFI or RIG $(\mathrm{P}>0.05)$. The same results were obtained by Bonilha et al. (2013) and Zorzi et al. (2013).

Efficient animals in both indexes (RFI and RIG) had greater longissimus muscle area $(P>0.05$, Table 6$)$. These results corroborate with those found by Santana et al. (2012), who observed greater longissimus muscle area, suggesting greater muscle deposition on the carcass of efficient-RFI Nellore steers.

Since subcutaneous fat thickness was used as a criterion to determine the harvest point, no significant relationships at slaughter were observed between BFT and RFI or RIG $(\mathrm{P}>0.05)$. However, differences in body composition could be a possible explanation to lower DMI observed for efficient animals.

Although energy concentration of lipids are twofold that of protein (9.5 versus $5.5 \mathrm{kcal} / \mathrm{g}$ ), muscle deposition is more efficient, since each gram of protein deposited in the gain carries 3-4 g of water, meaning that efficiency of energy use is higher to muscle tissue deposition than to adipose tissue deposition, resulting in a greater amount of tissue deposited for the same amount of energy intake with lower energy content of gain (Lofgreen \& Garrett, 1968).

Table 6

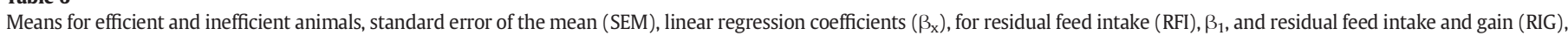
$\beta_{2}$, and probability level for non-carcass traits of 575 Nellore steers.

\begin{tabular}{|c|c|c|c|c|c|c|c|c|c|c|}
\hline \multirow[t]{2}{*}{ Traits } & \multicolumn{5}{|l|}{ RFI } & \multicolumn{5}{|l|}{ RIG } \\
\hline & Efficient & Inefficient & SEM & $\beta_{1}$ & P-value & Efficient & Inefficient & SEM & $\beta_{2}$ & P-value \\
\hline \multicolumn{11}{|l|}{$\mathrm{N}=575$} \\
\hline Heart, kg & 1.49 & 1.47 & 0.02 & -0.01 & 0.46 & 1.50 & 1.46 & 0.02 & 0.01 & 0.05 \\
\hline Kidney, kg & 0.81 & 0.82 & 0.01 & 0.01 & 0.32 & 0.83 & 0.82 & 0.01 & 0.00 & 0.30 \\
\hline Liver, $\mathrm{kg}$ & 4.82 & 4.93 & 0.03 & 0.08 & 0.05 & 4.92 & 4.84 & 0.14 & 0.02 & 0.12 \\
\hline Perirenal fat, kg & 5.08 & 5.08 & 0.19 & -0.00 & 0.99 & 5.12 & 5.04 & 0.19 & 0.02 & 0.59 \\
\hline Inguinal fat, $\mathrm{kg}$ & 6.11 & 6.17 & 0.25 & 0.06 & 0.77 & 6.27 & 5.99 & 0.23 & 007 & 0.19 \\
\hline Pelvic fat, kg & 4.94 & 4.96 & 0.34 & 0.02 & 0.89 & 5.08 & 4.83 & 0.33 & 0.06 & 0.14 \\
\hline \multicolumn{11}{|c|}{$\mathrm{g} / \mathrm{kg}$ of hot carcass weight } \\
\hline Heart & 5.79 & 5.85 & 0.06 & 0.04 & 0.44 & 5.79 & 5.85 & 0.06 & -0.02 & 0.39 \\
\hline Kidney & 3.18 & 3.28 & 0.04 & 0.07 & 0.12 & 3.21 & 3.24 & 0.05 & -0.01 & 0.64 \\
\hline Liver & 18.7 & 19.5 & 0.35 & 0.57 & $<0.0001$ & 18.9 & 19.3 & 0.37 & -0.10 & 0.05 \\
\hline Perirenal fat & 19.4 & 19.7 & 0.51 & 0.19 & 0.60 & 19.5 & 19.6 & 0.58 & -0.03 & 0.81 \\
\hline Inguinal fat & 25.1 & 26.1 & 1.33 & 0.72 & 0.18 & 25.2 & 25.7 & 0.73 & -0.13 & 0.49 \\
\hline Pelvic fat & 19.9 & 20.8 & 1.23 & 0.57 & 0.81 & 20.1 & 20.4 & 1.27 & -0.08 & 0.60 \\
\hline
\end{tabular}


Table 7

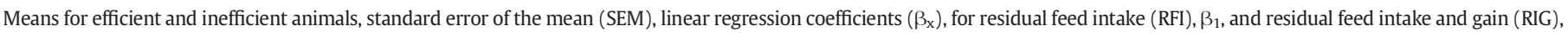
$\beta_{2}$, and probability level for $\mathrm{pH}$, holding water capacity, cooking losses and intramuscular ether extract content of meat non-aged and aged during 7 or $14 \mathrm{~d}$ of 511 Nellore steers.

\begin{tabular}{|c|c|c|c|c|c|c|c|c|c|c|}
\hline \multirow{3}{*}{ Traits } & \multicolumn{10}{|l|}{$\mathrm{N}=512$} \\
\hline & \multicolumn{5}{|l|}{ RFI } & \multicolumn{5}{|l|}{ RIG } \\
\hline & Efficient & Inefficient & SEM & $\beta_{1}$ & P-value & Efficient & Inefficient & SEM & $\beta_{2}$ & P-value \\
\hline \multicolumn{11}{|l|}{$\mathrm{pH}^{\mathrm{a}}$} \\
\hline $0 \mathrm{~d}$ aging & 5.59 & 5.59 & 0.12 & -0.00 & 0.35 & 5.60 & 5.59 & 0.11 & 0.003 & 0.22 \\
\hline $7 \mathrm{~d}$ aging & 5.56 & 5.55 & 0.01 & -0.01 & 0.24 & 5.56 & 5.55 & 0.01 & 0.003 & 0.06 \\
\hline $14 \mathrm{~d}$ aging & 5.56 & 5.55 & 0.01 & -0.01 & 0.18 & 5.56 & 5.55 & 0.02 & 0.002 & 0.24 \\
\hline \multicolumn{11}{|l|}{ Holding water capacity, \% } \\
\hline $0 \mathrm{~d}$ aging & 74.7 & 74.1 & 0.59 & -0.44 & 0.15 & 74.5 & 74.3 & 0.64 & 0.01 & 0.54 \\
\hline $7 \mathrm{~d}$ aging & 63.9 & 63.2 & 1.06 & -0.52 & 0.06 & 64.0 & 63.1 & 1.09 & 0.01 & 0.15 \\
\hline $14 \mathrm{~d}$ aging & 63.7 & 63.4 & 0.54 & -0.23 & 0.44 & 63.7 & 63.8 & 0.60 & 0.12 & 0.29 \\
\hline \multicolumn{11}{|l|}{ Cooking losses, $\%{ }^{\mathrm{a}}$} \\
\hline $0 \mathrm{~d}$ aging & 29.2 & 28.6 & 0.32 & -0.35 & 0.20 & 29.1 & 28.7 & 0.306 & 0.102 & 0.30 \\
\hline $7 \mathrm{~d}$ aging & 28.2 & 28.0 & 0.63 & -0.08 & 0.82 & 28.1 & 28.0 & 0.63 & 0.022 & 0.87 \\
\hline $14 \mathrm{~d}$ aging & 27.5 & 27.6 & 0.40 & 0.06 & 0.87 & 27.7 & 27.3 & 0.40 & 0.104 & 0.44 \\
\hline Intramuscular EE content, \% & 2.84 & 3.22 & 0.11 & 0.27 & 0.0003 & 2.85 & 3.21 & 0.11 & -0.09 & 0.001 \\
\hline
\end{tabular}

a Longissimus sample.

b Longissimus non-aged sample.

No significant relationships between RFI or RIG and proportions ( $\mathrm{g} / \mathrm{kg} \mathrm{HCW}$ ) of heart, kidney, and perirenal, inguinal and pelvic fat were observed $(P>0.05$; Table 6$)$. Similar results have been reported in the literature (Bonilha et al., 2013; Cruz et al., 2010; Fitzsimons, Kenny, \& Mcgee, 2014; Gomes et al., 2012; Mader et al., 2009). However, efficient (RFI and RIG) animals had lower proportion of liver compared to the inefficient ones $(\mathrm{P}<0.05)$.

According to Carstens and Kerley (2009), visceral tissues such as heart, kidneys and liver, which have higher protein turnover than skeletal muscles, consume around $20-25 \%$ of the daily energy intake of animals and may account for up to $30 \%$ of the daily heat production. From daily heat production, approximately $38-46 \%$ of the losses occur in the gastrointestinal tract and 19-22\% in skeletal muscles (Lobley, Milne, Lovie, Reeds, \& Pennie, 1980).

Thus, the observed lower intake of efficient animals may be attributed to the reduction of energy requirements as they have lower liver proportion. Furthermore, in response to the higher DMI to attend higher requirements of animals, the liver increases in size and weight (Fox, Sniffen, O'Connor, Russell, \& Van Soest, 1992). Basarab et al. (2003) also found lower liver weight in low-RFI animals compared to highRFI steers.

Information about non-carcass components are relevant, since the beef industry does not pay for these components, therefore higher efficiency with reduced visceral fat deposition is desired. However, care should be taken considering the consequences for females, since visceral fat may be important for reproductive processes mainly for cows on grazing systems, where seasonality of forage production may bring nutritional challenges that can make body fat even more important.

\subsection{Meat quality traits}

RFI and RIG were not related to $\mathrm{pH}$ regardless of aging time $(\mathrm{P}>0.05$; Table 7). The observed $\mathrm{pH}$ was consistent with that recommended by the industry (final $\mathrm{pH}$ below 5.7) to ensure color and meat quality, and are similar to other reported values for Nellore (Gomes et al., 2012; Pflanzer \& de Felício, 2009; Zorzi et al., 2013).

Table 8

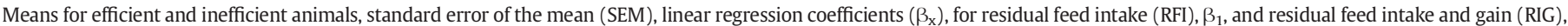
$\beta_{2}$, and probability level for color traits on meat non-aged and aged during 7 or $14 \mathrm{~d}$ and on subcutaneous fat of 511 Nellore steers.

\begin{tabular}{|c|c|c|c|c|c|c|c|c|c|c|}
\hline \multirow{3}{*}{ Traits } & \multicolumn{10}{|l|}{$\mathrm{N}=512$} \\
\hline & \multicolumn{5}{|l|}{ RFI } & \multicolumn{5}{|l|}{ RIG } \\
\hline & Efficient & Inefficient & SEM & $\beta_{1}$ & P-value & Efficient & Inefficient & SEM & $\beta_{2}$ & P-value \\
\hline \multicolumn{11}{|l|}{0 d aging } \\
\hline $\mathrm{L}^{*}$ & 39.4 & 40.0 & 0.18 & 0.40 & 0.01 & 39.6 & 39.8 & 0.21 & -0.07 & 0.22 \\
\hline$a^{*}$ & 19.5 & 19.7 & 0.14 & 0.15 & 0.21 & 19.5 & 19.7 & 0.17 & -0.05 & 0.22 \\
\hline$b^{*}$ & 14.9 & 15.1 & 0.14 & 0.13 & 0.10 & 14.9 & 15.1 & 0.15 & -0.04 & 0.16 \\
\hline$a^{*} / b^{*}$ & 1.30 & 1.30 & 0.01 & -0.00 & 0.87 & 1.30 & 1.30 & 0.01 & 0.00 & 0.98 \\
\hline $\mathrm{L}^{*}$ subcutaneous fat & 76.3 & 76.1 & 0.32 & -0.12 & 0.56 & 76.3 & 76.1 & 0.35 & 0.07 & 0.37 \\
\hline$a^{*}$ subcutaneous fat & 10.2 & 10.1 & 0.41 & -0.05 & 0.74 & 10.2 & 10.2 & 0.43 & 0.02 & 0.67 \\
\hline $\mathrm{b}^{*}$ subcutaneous fat & 18.1 & 18.2 & 0.27 & 0.08 & 0.61 & 18.2 & 18.2 & 0.30 & 0.01 & 0.93 \\
\hline \multicolumn{11}{|l|}{$7 d$ aging } \\
\hline $\mathrm{L}^{*}$ & 39.1 & 39.5 & 0.37 & 0.30 & 0.07 & 39.2 & 39.4 & 0.36 & -0.065 & 0.31 \\
\hline$a^{*}$ & 17.0 & 16.9 & 0.38 & -0.04 & 0.71 & 16.9 & 17.0 & 0.38 & -0.019 & 0.62 \\
\hline $\mathrm{b}^{*}$ & 15.0 & 15.1 & 0.28 & 0.07 & 0.42 & 15.0 & 15.2 & 0.28 & -0.033 & 0.31 \\
\hline$a^{*} / b^{*}$ & 1.13 & 1.12 & 0.03 & -0.01 & 0.25 & 1.13 & 1.12 & 0.03 & 0.00 & 0.58 \\
\hline \multicolumn{11}{|l|}{14 d aging } \\
\hline $\mathrm{L}^{*}$ & 40.4 & 40.7 & 0.24 & 0.20 & 0.24 & 40.5 & 40.7 & 0.27 & -0.05 & 0.41 \\
\hline$a^{*}$ & 17.4 & 17.3 & 0.42 & -0.09 & 0.39 & 17.4 & 17.3 & 0.42 & 0.04 & 0.35 \\
\hline$b^{*}$ & 15.4 & 15.5 & 0.30 & 0.05 & 0.54 & 15.4 & 15.5 & 0.30 & -0.02 & 0.56 \\
\hline$a^{*} / b^{*}$ & 1.13 & 1.12 & 0.01 & -0.01 & 0.18 & 1.13 & 1.12 & 0.01 & 0.00 & 0.12 \\
\hline
\end{tabular}


Table 9

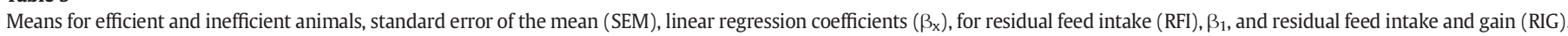
$\beta_{2}$, and probability level for tenderness traits on meat non-aged and aged during 7 or $14 \mathrm{~d}$ and on subcutaneous fat of 511 Nellore steers.

\begin{tabular}{|c|c|c|c|c|c|c|c|c|c|c|}
\hline \multirow[t]{2}{*}{ Traits } & \multicolumn{5}{|l|}{ RFI } & \multicolumn{5}{|l|}{ RIG } \\
\hline & Efficient & Inefficient & SEM & $\beta_{1}$ & P-value & Efficient & Inefficient & SEM & $\beta_{2}$ & P-value \\
\hline Shear force, $\mathrm{kg} / \mathrm{cm}^{2}-0 \mathrm{~d}$ & 8.97 & 8.66 & 0.27 & -0.21 & 0.05 & 8.92 & 8.70 & 0.33 & 0.06 & 0.16 \\
\hline Shear force, $\mathrm{kg} / \mathrm{cm}^{2}-7 \mathrm{~d}$ & 5.89 & 5.86 & 0.21 & -0.02 & 0.85 & 5.92 & 5.83 & 0.23 & 0.02 & 0.61 \\
\hline Shear force, $\mathrm{kg} / \mathrm{cm}^{2}-14 \mathrm{~d}$ & 4.60 & 4.60 & 0.15 & 0.01 & 0.95 & 4.65 & 4.55 & 0.17 & 0.02 & 0.49 \\
\hline Myofibrillar fragmentation index & 48.7 & 49.0 & 3.76 & 0.18 & 0.91 & 48.2 & 49.5 & 3.76 & -0.34 & 0.59 \\
\hline
\end{tabular}

Cooking losses (\%) were not affected by RFI or RIG regardless of the aging time $(\mathrm{P}>0.05$; Table 7$)$ in agreement with results found by Gomes et al. (2012) and Zorzi et al. (2013). The holding water capacity (HWC) was not related to RIF or RIG $(P>0.05)$ and the observed values for non-aged samples were similar to those found by Fernandes et al. (2009) for Nellore.

Extracted intramuscular fat was lower in efficient animals for both indexes $(\mathrm{P}<0.05)$, corroborating results obtained by other authors (Richardson et al., 2001; Welch et al., 2012). The higher extracted intramuscular fat deposited by inefficient animals can partially explain the higher intake to ensure sufficient energy for the intramuscular fat deposition. Intramuscular fat is an important component of meat quality in beef cattle production systems, because it is directly linked to meat palatability and carcass value, key aspects to determine marketing and return on investment (Welch et al., 2012).

Meat lightness observed in this study was within expected range for the final pH observed. No significant effects were observed between RFI or RIG and lightness $\left(\mathrm{L}^{*}\right)$, red intensity $\left(\mathrm{a}^{*}\right)$, yellow intensity $\left(\mathrm{b}^{*}\right)$ and $\mathrm{a}^{*} / \mathrm{b}^{*}$ ratio regardless of the aging time $(\mathrm{P}<0.05$; Table 8$)$, except $\mathrm{L}^{*}$ of non-aged meat where RFI-inefficient animals showed lighter meat than inefficient animals $(\mathrm{P}<0.05)$ possibly due to the higher extracted intramuscular fat in these animals (Table 7), however, the lightness variation observed would most probably not be perceived by consumers. This result corroborates Ślósarz et al. (2004), who observed higher lightness in meat with higher extracted intramuscular fat. Other authors found no differences in lightness and meat color in RFIefficient and inefficient animals (Gomes et al., 2012; Perkins et al., 2014; Zorzi et al., 2013). Muchenje et al. (2009) observed averages from 33.2 to $41.0,11.1$ to 23.6 and from 6.1 to 11.3 for $\mathrm{L}^{*}$, $\mathrm{a}^{*}$ and $\mathrm{b}^{*}$, respectively. No significant relationship was observed between RFI or RIG and $\mathrm{L}^{*}, \mathrm{a}^{*}$ and $\mathrm{b}^{*}$ of fat on non-aged steaks $(\mathrm{P}>0.05)$. McDonagh et al. (2001) observed no differences in fat color between RFI-efficient and inefficient animals. Perkins et al. (2014) found the same results evaluating fat color of meat samples of Angus steers finished in feedlot.

The shear force was not related to RIG regardless of the aging period $(P>0.05)$, RFI-efficient animals had higher shear force for non-aged meat compared to inefficient ones $(P<0.05$; Table 9), however, although this was a statistically significant difference, in reality would be too small to be detected by a trained sensory panel. This effect was not observed $(\mathrm{P}>0.05)$ for aged meat, showing that this process can counter-act the effect of feed efficiency on meat tenderness. Similar results were found by Zorzi et al. (2013) where low-RFI bulls had higher shear force compared to high-RFI bulls. Some studies relate feed efficiency and meat quality evaluation in Europe (Ahola et al., 2011; Baker et al., 2006; McDonagh et al., 2001), and for zebu cattle, some studies (Farjalla, 2009; Gomes et al., 2012; Welch et al., 2012) found no relationship between RFI and shear force in non-aged and aged steaks. Although the results in literature for meat quality of efficient animals are still contradictory, some evidence show that selection for low RFI would negatively affect meat tenderness (Herd \& Pitchford, 2011).

The myofibrillar fragmentation index of non-aged samples was not related to RFI or RIG (Table 9; P>0.05). Considering MFI as an indicator of meat tenderness, Culler, Parrish, Smith, and Cross (1978) reported that values above 60 corresponds to extremely tender meat, between
50 and 60 indicate moderately tender, while below 50 indicate tough meat. Therefore, in this study, the non-aged meat could be considered tough, in accordance to the high SF observed. Gomes et al. (2012) and Zorzi et al. (2013) found lower MFI in RFI-efficient animals (low-RFI) compared to RFI-inefficient animals (high-RFI). In both studies, the values were below 50 classifying the non-aged sample as tough meat.

\section{Conclusions}

Improving feed efficiency affects meat quality, especially in regard to intramuscular fat, which decreased as efficiency increased. Although color lightness and tenderness of un-aged meat were significantly associated with RFI, these relationships were not significant after aging.

\section{References}

ABIEC (2014). Brazilian Beef Exporter Association. Statistic reports (http://www.abiec com.br/estatisticas/).

Ahola, J. K., Skow, T. A., Hunt, C. W., \& Hill, R. A. (2011). Relationship between residual feed intake and end product palatability in longissimus steaks from steers sired by Angus bulls divergent for intramuscular fat expected progeny difference. 27. (pp. 109-115). American Registry of Professional Animal Scientists, 109-115.

AOAC (2006). Official methods of analysis (18th ed.). Arlington, VA, USA: AOAC International.

Arthur, P. F., Archer, J. A., Herd, R. M., \& Melville, G. J. (2001). Response to selection for net feed intake in beef cattle. In: Assoc. for the Advanc. of Animal Breeding and Genetics. Queenstown: Livestock Library, 135-138.

Baker, S. D., Szasz, J. I., Klein, T. A., Kuber, P. S., Hunt, C. W., \& Glaze, J. B., Jr. (2006). Residual feed intake of purebred Angus steers: Effects on meat quality and palatability. Journal of Animal Science, 84, 938-945.

Barros, G. C., \& Vianni, M. C. E. (1979). Tecnologia aplicada às carnes bovina, suína e de aves, da produção ao consumo. Seropédica: Universidade Federal Rural do Rio de Janeiro (116 pp.).

Basarab, J. A., Price, M. A., Aalhus, J. L., Okine, E. K., Snelling, W. M., \& Lyle, K. L. (2003). Residual feed intake and body composition in young growing cattle. Canadian Journal of Animal Science, 83, 189-204.

Berry, D. P., \& Crowley, J. J. (2012). Residual intake and gain: A new measure of efficiency in growing cattle. Journal of Animal Science, 90, 109-115.

Bonilha, E. F. M., Branco, R. H., Bonilha, S. F. M., Araújo, F. L., Magnani, E., \& Mercadante, M. E. Z. (2013). Body chemical composition of Nellore bulls with different residual feed intakes. Journal of Animal Science, 91(7), 3457-3464.

Cancian, P. H., Gomes, R. C., Manicardi, F. R., Ianni, A. C., Bonin, M. N., Leme, P. R., \& Luz E Silva, S. (2014). Correlations of visual scores, carcass traits, feed efficiency and retail product yield in Nellore cattle. Scientia Agricola, 71(1), 17-22.

Carstens, G. E., \& Kerley, M. S. (2009). Biological basis for variation in energetic efficiency of beef cattle. Proceedings of the Beef Improvement Federation 41st Annual Research Symposium, Conforth 30-May 3, Sacramento, California, USA (pp. 124-131).

CIE (1978). Recommendation on uniform colour spaces, colour difference equations, psychometric colour terms. Supplement No. 2 to publication CIE no.15 (e-1.3.1)Paris: Commission Internationale De L'Eclairage.

Cruz, G. D., Rodriguez-Sanchez, J. A., Oltjen, J. W., \& Sainz, R. D. (2010). Performance, residual feed intake, digestibility, carcass traits, and profitability of Angus-Hereford steers housed in individual or group pens. Journal of Animal Science, 88, 324-329.

Culler, R. D., Parrish, F. C., Smith, G. C., \& Cross, H. R. (1978). Relationship of myofibril fragmentation index to certain chemical, physical and sensory characteristics of bovine longissimus muscle. Journal of Food Science, 43(4), 1177-1180.

Farjalla, Y. B. (2009). Desempenho, características de carcaça e qualidade de carne de bovinos Nelore estratificados pela eficiência alimentar através do consumo alimentar residual. 57 p. Dissertation (Master of Animal Science and Pastures) Piracicaba: University of São Paulo (http://www.teses.usp.br/teses/disponiveis/11/11139/tde26022010-082854/ pt-br.php).

Fernandes, A. R. M., Sampaio, A. A. M., Wignez, H., Oliveira, E. A., Oliveira, R. V., \& Leonel, F. R. (2009). Composição em ácidos graxos e qualidade da carne de tourinhos Nelore e Canchim alimentados com dietas à base de cana-de-açúcar e dois níveis de concentrado. Revista Brasileira de Zootecnia, 38(2), 328-337. 
Ferrell, C. L. \& Jenkins, T. G. (1998). Body composition and energy utilization by steers of diverse genotypes fed a high-concentrate diet during the finishing period: I. Angus, Belgian Blue, Hereford, and Piedmontese sires. Journal of Animal Science, 76, 637-646.

Fitzsimons, C., Kenny, D. A., \& Mcgee, M. (2014). Visceral organ weights, digestion and carcass characteristics of beef bulls differing in residual feed intake offered a high concentrate diet. Animal, 8(6), 949-959.

Fox, D. G., Sniffen, C. J., O'Connor, J. D., Russell, J. B., \& Van Soest, P. J. (1992). A net carbohydrate and protein system for evaluating cattle diets: III. Cattle requirements and diet adequacy. Journal of Animal Science, 70, 3578-3596.

Gomes, R. C., Sainz, R. D., Silva, S. L., César, M. C., Bonin, M. N., \& Leme, P. R. (2012). Feedlot performance, feed efficiency reranking, carcass traits, body composition, energy requirements, meat quality and calpain system activity in Nellore steers with low and high residual feed intake. Livestock Science, 150, 265-273.

Grau, R., \& Hamm, R. A. (1953). A simple method for the determination of water binding in muscles. Naturwissenschaften, 40, 29-30.

Herd, R. M., \& Bishop, S. C. (2000). Genetic variation in residual feed intake and its association with other production traits in British Hereford cattle. Livestock Production Science, 63, 111-119.

Herd, R. M., \& Pitchford, W. S. (2011). Residual feed intake selection makes cattle leaner and more efficient. Recent Advances in Animal Nutrition, 18, 45-58.

Honikel, K. O. (1998). Reference methods for the assessment of physical characteristics of meat. Meat Science, 49, 447-457.

Hopkins, D. L., Littlefeld, P. J., \& Thompson, J. M. (2000). A research note on factors affecting the determination of myofibrillar fragmentation. Meat Science, 56, 19-22.

IBGE (2014). Brazilian Institute of Geography and Statistics. (http://www.sidra.ibge.gov.br/ $\mathrm{bda} /$ pecua $/$ default.asp $\mathrm{t}=4 \& \mathrm{z}=\mathrm{t} \& \mathrm{o}=24 \& \mathrm{u} 1=1 \& \mathrm{u} 2=1 \& \mathrm{u} 31 \& \mathrm{u} 4=1 \& \mathrm{u} 5=1 \& \mathrm{u} 6=$ $1 \& u 7=1)$.

Jones, F. M., Philips, F. A., Naylor, T., \& Mercer, N. B. (2011). Methane emissions from grazing Angus beef cows selected for divergent residual feed intake. Animal Feed Science and Technology, 166-167, 302-307.

Khiaosa-Ard, \& Zebeli, Q. (2014). Cattle's variation in rumen ecology and metabolism and its contributions to feed efficiency. Livestock Science, 162, 66-75.

Koch, R. M., Swigwr, L. A., Chambers, D., \& Gregory, K. E. (1963). Efficiency of feed use in beef cattle. Journal of Animal Science, 22, 486-494.

Licitra, G., Hernandez, T. M., \& Van Soest, P. J. (1996). Standardization of procedures for nitrogen fractionation of ruminant feeds. Animal Feed Science and Technology, 57 347-358.

Lobley, G. E., Milne, V., Lovie, J. M., Reeds, P. J., \& Pennie, K. (1980). Whole body and tissue protein synthesis in cattle. British Journal of Nutrition, 43, 491.

Lofgreen, G. P., \& Garrett, W. N. (1968). A system for expressing the energy requirements and feed values for growing and finishing cattle. Journal of Animal Science, 27, 793-806.

Lucila Sobrinho, T., Branco, R. H., Bonilha, S. F. M., Castilhos, A. M., Figueiredo, L. A., Razook A. G., \& Mercadante, M. E. Z. (2011). Residual feed intake and relationships with performance of Nellore cattle selected for post weaning weight. Revista Brasileira de Zootecnia, 40(4), 929-937.

Mader, C. J., Montanholi, Y. R., Wang, Y. J., Miller, S. P., Mandell, I. B., McBride, B. W., \& Swanson, K. C. (2009). Relationships among measures of growth performance and efficiency with carcass traits, visceral organ mass, and pan-creatic digestive enzymes in feedlot cattle. Journal of Animal Science, 87, 1548-1557.

McDonagh, M. B., Herd, R. M., Richardson, E. C., Oddy, V. H., Archer, J. A., \& Arthur, P. F. (2001). Meat quality and the calpain system of feedlot steers following a single generation of divergent selection for residual feed intake. Australian Journal of Experimental Agriculture, 41, 1013-1021.

Muchenje, V., Dzama, K., Chimonyo, M., Strydom, P. E., Hugo, A., \& Raats, J. G. (2009). Some biochemical aspects pertaining to beef eating quality and consumer health: A review. Food Chemistry, 112(2), 270-289.
Nkrumah, J. D., Basarab, J. A., Price, M. A., Okine, E. K., Ammoura, A., Guercio, S., ... Moore, S. S. (2004). Different measures of energetic efficiency and their phenotypic relationships with growth, feed intake, and ultrasound and carcass merit in hybrid cattle. Journal of Animal Science, 82, 2451-2459.

Nkrumah, J. D. Basarab, J. A. Wang Z. Li, C., Price, M. A., Okine, E. K.... Moore, S. S. (2007) Genetic and phenotypic relationships of feed intake and different measures of feed efficiency with growth and carcass merit of beef cattle. Journal of Animal Science, 85, 2711-2720.

NATIONAL RESEARCH COUNCIL - NRC (2001). Nutrient requeriments of dairy cattle (7.rev. ed.) Washinton, D.C.: 2001. 381p

Perkins, S. D., Key, C. N., Garrett, C. F., Foradori, C. D., Bratcher, C. L., Kriese-Anderson, L. A., \& Brandebourg, T. D. (2014). Residual feed intake studies in Angus-sired cattle reveal a potential role for hypothalamic gene expression in regulating feed efficiency. Journal of Animal Science, 92, 549-560.

Pflanzer, S. B. \& de Felício, P. E. (2009). Effects of teeth maturity and fatness of Nellore (Bos indicus) steer carcasses on instrumental and sensory tenderness. Meat Science, 83(4), 697-701.

Ramos, E. M., \& Gomide, L. A. (2007). Avaliação da qualidade de carnes: fundamentos e metodologias. Viçosa: Ed. UFV (559 pp.).

Retallick, K. (2013). Evaluation of feedlot feed efficiency relationships as well as genetic and phenotypic performance, carcass, and economic outcomes. $102 \mathrm{p}$. Dissertation (PhD in Animal Sciences) University of Illinois, Urbana-Champaign (https://www.ideals. illinois.edu/handle/2142/42433).

Richardson, E. C., Herd, R. M., Oddy, V. H., Thompson, J. M., Archer, J. A., \& Arthur, P. F. (2001). Body composition and implications for heat production and Angus steer progeny of parents selected for and against residual feed intake. Australian Journal of Experimental Agriculture, 41(7), 1065-1072.

Santana, M. H. A., Oliveira Junior, G. A., Gomes, R. C., Silva, S. L., Leme, P. R., Stella, T. R., ... Ferraz, J. B. S. (2014). Genetic parameter estimates for feed efficiency and dry matter intake and their association with growth and carcass traits in Nellore cattle. Livestock Science, 167, 80-85.

Santana, M. H. A., Rossi Junior, P., Almeida, R., \& Cucco, D. C. (2012). Feed efficiency and its correlations with carcass traits measured by ultrasound in Nellore bulls. Livestock Science, 145, 252-257.

SAS INSTITUTE (2012). SAS/STAT: guide of personal computers; version 9.3. Cary.

Ślósarz, P. Stanisz, M. Pietrzak, M. Gut, A Łyczyński, A \& Steppa, R (2004). The use of computer image analysis for evaluation of selected meat quality indices in lambs. Archiv fur Tierzucht, 47, 169-174.

Van Soest, P. J., Robertson, J. B., \& Lewis, B. A. (1991). Methods for dietary fiber, neutral detergent fiber, and no starch polysaccharides in relation to animal nutrition. Journal of Dairy Science, 74, 3597-3597.

Weiss, W. P., Conrad, H. R., \& Pierre, N. R. (1992). A theoretically-based model for predicting total digestible nutrient values of forages and concentrates. Animal Feed Science and Technology, 39, 95-110.

Welch, C. M., Ahola, J. K., Hall, J. B., Murdoch, G. K., Crews Jr., D. H., Davis, L. C., ... Hill, R. A. (2012). Relationships among performance, residual feed intake, and product quality of progeny from Red Angus sires divergent for maintenance energy EPD. Journal of Animal Science, 90(13), 5107-5117.

Wheeler, T. L., Koomarie, M., \& Shalckelford, S. D. (2005). Standardized Warner-Bratzler shear force procedures for meat tenderness measurement. (http://www.ars.usda.gov/ SP2UserFiles/Place/30400510/protocols/ShearForceProcedures.pdf).

Zorzi, K., Bonilha, S. F. M., Queiroz, A. C., Branco, B. R. H., Sobrinho, T. L., \& Duarte, M. S. (2013). Meat quality of young Nellore bulls with low and high residual feed intake. Meat Science, 93, 593-599. 